\title{
MENURUNKAN PERILAKU ANTISOSIAL SISWA MELALUI KONSELING KELOMPOK BERPUSAT PADA KLIEN YANG BERORIENTASI RELIGIUS
}

\author{
Srimurniasih $^{1}$, Mungin Eddy Wibowo ${ }^{2}$, Ali Murtadho ${ }^{3}$ \\ ${ }^{1}$ SMA Negeri 1 Kersana Brebes \\ ${ }^{2}$ Program Pascasarjana Bimbingan Konseling, Universitas Negeri Semarang \\ ${ }^{3}$ Fakultas Dakwah dan Komunikasi UIN Walisongo Semarang \\ E-mail: srimurniasih1975@gmail.com
}

\begin{abstract}
Abstrak
Tujuan penelitian ini adalah (1) Mendeskripsikan keterlaksanaan konseling kelompok melalui pendekatan berpusat pada klien yang berorientasi religius untuk menurunkan perilaku anti social siswa. (2) Menganalisis keefektifan konseling kelompok melalui pendekatan berpusat pada klien yang berorientasi religius untuk menurunkan perilaku anti sosial siswa. Metode penelitian menggunakan metode true eksperimental dengan desain pretes-post control group. Teknik pengumpulan data menggunakan kuesioner, dan dokumentasi. Teknik analisis data menggunakan statistik deskriptif, dan statistik inferensial dengan uji beda rata-rata. Hasil penelitian menyimpulkan bahwa (1) Keterlaksanaan konseling kelompok melalui pendekatan berpusat pada klien yang berorientasi religius mencapai $86,67 \%$ yang termasuk kategori sangat baik. (2) Layanan konseling kelompok melalui pendekatan berpusat pada klien yang berorientasi religius efektif untuk menurunkan perilaku antisocial siswa yang dibuktikan dengan nilai $Z_{\text {hitung }} 2,032>$ $\mathrm{t}_{\text {table }} 1,96$ dengan nilai probabilitas $(p$ value) $\mathbf{0 , 0 4 2}<\mathbf{0 , 0 5}$, dengan nilai indeks gain 0,475 yang termasuk kategori sedang.
\end{abstract}

Kata kunci: Konseling Kelompok; Berpusat pada Klien; Religius, Perilaku Antisosial

\begin{abstract}
The objectives of this study was (1) To describe the implementation of group counseling through a religiously oriented client-centered approach to reduce students' anti-social behavior (2) Analyze the effectiveness of group counseling through a client-centered approach that is religiously oriented to reduce students' anti-social behavior. The research method uses true experimental methods with pretest-post control group design. Data collection techniques used questionnaires, and documentation. Data analysis techniques used descriptive statistics, and inferential statistics with the average difference test. The results of the study concluded that (1) The implementation of group counseling through a client-centered, religiously oriented approach reached $86.67 \%$ which was included in the excellent category. (2) Group counseling services through a religiously oriented client-centered approach are effective in reducing students' antisocial behavior as evidenced by a Zhitung value of $2.032>$ ttable 1.96 with a probability value ( $p$ value) $0.042<0.05$, with a gain index value of 0.475 which including the medium category
\end{abstract}

Keywords: Group Counseling; Client Centered; religious; Antisocial Behavior

\section{Info Artikel}

Diterima Februari 2020, disetujui Maret 2020, diterbitkan Juni 2020 


\section{PENDAHULUAN}

Observasi awal yang telah dilaksanakan terhadap siswa di SMA Negeri 1 Kersana didapat informasi rendahnya perilaku religius siswa disebabkan kondisi sosial ekonomi dan geografis tempat tinggal siswa. Informasi data pribadi siswa yang ada di BP/BK tahun Ajaran 2019/2020 diketahui bahwa sebagian besar walimurid bekerja sebagai petani, buruh dan pedagang kecil. Kondisi geografis tempat tinggal siswa dan sekolah yang berada di pegunungan menyebabkan minimnya akses pekerjaan sehingga banyak dari orang tua siswa bekerja di luar kota sehingga orangtua kurang memiliki waktu untuk membimbing karakter religious siswa dalam melewati masa-masa perkembangannya yang masih membutuhkan dukungan dan bantuan dari orangtua dalam mengatasi masalah-masalah pribadi maupun kehidupan sosialnya.

Salah satu layanan dalam bimbingan konseling adalah konseling kelompok. Konseling kelompok dapat menjadi alternatif layanan yang dapat dilaksanakan untuk menyelesaikan permasalahan secara efektif dan efisien. Menurut Wibowo (2019) bahwa konseling kelompok adalah suatu kegiatan dalam pemberian layanan yang dilakukan oleh konselor kepada klien yang bermasalah secara berkelompok.

Sementara menurut Prayitno, (2008) bahwa konseling kelompok merupakan suatu upaya pemberian bantuan kepada siswa melalui kelompok untuk mendapatkan informasi yang berguna agar dapat menyelesaikan masalah yang dihadapi, mampu menyusun rencana, mampu membuat keputusan yang tepat, serta untuk memperbaiki dan mengembangkan pemahaman terhadap diri sendiri, orang lain, lingkungan dalam membentuk perilaku yang lebih efektif di sekolah.

Konseling kelompok adalah proses interpersonal yang dipimpin oleh konselor yang terlatih secara profesional dan dilaksanakan dengan individu-individu yang sedang menghadapi problema perkembangan khusus. Hal itu berfokus pada pikiran, perasaan, sikap, nilai, tujuan tingkah laku dan tujuan individu dan grup secara keseluruhan.

Permasalahan tersebut disebabkan karena banyak sumber yang tidak hanya di dalam sekolah, tetapi bisa juga dalam keluarga dimana siswa kurang mempunyai empati pada orang lain yang menyebabkan perilaku prososialnya kurang tercipta dengan baik dan hal ini bisa terlihat dalam kehidupan sehari-hari siswa selama di lingkungan sekolah. Untuk mengatasi hal tersebut, maka diperlukan teknik dalam menjawab persoalan yang ada saat ini karena metode konvensional yang selama ini dipakai sudah tidak relevan lagi. 
Untuk itu perlu diupayakan metode yang relevan yang mampu menjawab persoalan yang ada. Salah satu upaya yang bisa ditempuh adalah dengan konseling kelompok menggunakan pendekatan berpusat pada klien (client centered therapy) yang memungkinkan adanya pendekatan tersebut untuk menurunkan perilaku antisosial yang ada pada diri siswa.

Menurut Setyawati (2013) pendekatan client centered merupakan pendekatan yang mengatakan bahwa siswa yang mempunyai masalah pada dasarnya tetap memiliki potensi dan mampu mengatasi masalahnya sendiri. Menurut Park (2018) bahwa pendekatan client centered memberi klien kesempatan untuk memilih kegiatan yang berarti bagi mereka sendiri dan memungkinkan klien dan terapis untuk menetapkan tujuan terapeutik bersama untuk mendorong partisipasi klien yang aktif. Pendekatan berpusat pada klien merupakan pendekatan yang bertujuan untuk membuat siswa lebih aktif, siswa yang kurang aktif menjadi aktif dalam bersosial.

Menurut Desousa (2014) pendekatan yang berpusat pada klien berfokus pada tanggung jawab dan kapasitas klien untuk menemukan cara-cara menghadapi kenyataan secara lebih penuh. Klien, yang paling mengenal dirinya sendiri, adalah orang yang menemukan perilaku yang lebih tepat untuk dirinya sendiri.

Teori berpusat pada klien merupakan teori yang dibangun berdasarkan penelitian dan observasi langsung terhadap peristiwa-peristiwa nyata yaitu dengan memandang siswa yang pada dasarnya baik, manusia sebagai makhuk sosial yang mempunyai empati pada orang lain karena siswa tidak bisa hidup sendiri tanpa bantuan orang lain. Akan tetapi ada juga yang egois dalam arti perilaku prososialnya kurang, sehingga hal ini bisa merugikan siswa lain. Untuk itulah dibutuhkan adanya pendekatan berpusat pada klien karena setiap siswa mempunyai watak dan perilaku yang berbeda-beda.

Penggunaan pendekatan berpusat pada klien yang ada di SMAN 1 Kersana Kabupaten Brebes ini dilakukan oleh pihak sekolah melalui guru BK yang dinilai mempunyai teknik atau metode yang bisa membuat siswa merasa nyaman untuk konsultasi terhadap kendala dan masalah yang dihadapi dalam dirinya dalam hal bersosial dengan teman.

Penelitian tentang konseling kelompok telah banyak dilakukan oleh para peneliti diantaranya bahwa konseling kelompok dapat mengurangi perilaku bullying dan agresif (Efastri et al, 2015), meningkatkan disiplin (Wibawa et al, 2015), meningkatkan self 
efficacy (Arizona et al, 2016; Azhari et al, 2016), meningkatkan resiliensi siswa (Khomsah et al, 2015), mengurangi prokrastinasi akademik (Puspita et al, 2016; mengurangi perilaku membolos (Hidayanti \& M Jafar, 2016), meningkatkan classroom engagement (Dwistia et al, 2016),

Penggunaan pendekatan ini juga dikuatkan dengan penelitian sebelumnya dari Nugraha (2017) yang berjudul Efektifitas Penggunaan Konseling Kelompok Dengan Teknik Client Centered Untuk Mengatasi Kenakalan Remaja Pada Siswa SMP Negeri 5 Karanganyar. Adapun tujuan penelitian yang dilakukan oleh Nugraha adalah untuk menguji tingkat keefektifan dalam penggunaan konseling kelompok dengan teknik Client Centered dalam mengatasi kenakalan siswa kelas SMP Negeri 5 Karanganyar. Dan hasil penelitian yang didapat bahwa penggunaan konseling kelompok dengan teknik Berpusat pada Klien sangat efektif serta mampu menurunkan kenakalan remaja pada siswa di SMP Negeri 5 Karanganyar.

Penelitian tentang pemberian bimbingan dan konseling melalui konseling kelompok dengan berbagai pendekatan dan metode telah banyak dilakukan. Namun konseling kelompok melalui pendekatan berpusat pada klien (client centered) yang berorientasi religius belum pernah dilakukan. Berdasarkan latar belakang dan identifikasi masalah, maka dapat dirumuskan masalah yang menjadi pertanyaan penelitian ini sebagai berikut : (1) Bagaimana keterlaksanaan konseling kelompok melalui pendekatan berpusat pada klien yang berorientasi religius untuk menurunkan perilaku antisosial siswa di SMAN 1 Kersana Brebes? (2) Bagaimana keefektifan konseling kelompok melalui pendekatan berpusat pada klien yang berorientasi religius untuk menurunkan perilaku anti sosial siswa di SMAN 1 Kersana Brebes?

\section{METODE PENELITIAN}

Pendekatan penelitian ini menggunakan true experimental dengan desain pretespostes control group, yang bertujuan untuk mengetahui sejauh mana layanan berpusat pada klien yang berorientasi religus dapat menurunkan perilaku antisocial siswa SMA Negri 1 Kersana. Subyek pada penelitian ini adalah siswa SMA yang duduk di kelas X. Populasi pada penelitian ini adalah siswa kelas X di SMA Negeri 1 Kersana. Teknik pengambilan sampel dilakukan secara purposive sebanyak dua kelompok dimana satu kelompok terdiri dari 7 responden siswa sebagai kelompok eksperimen, dan satu 
kelompok (7 responden) sebagai kelompok kontrol.

Dalam penelitian ini, peneliti menggunakan beberapa pengumpulan data, diantaranya 1) data perilaku antisosial siswa dilakukan dengan menggunakan metode kuesioner, 2) lembar observasi keterlaksanaan layanan, dan dan 3) data tanggapan siswa terhadap layanan konseling kelompok berpusat pada klien berorientasi religius. Sebelum dilakukan pengambilan data, instrumen dianalisis terlebih dahulu dengan cara divalidasi secara kontruk dan empiris. Secara konstruk instrumen yang telah dibuat divalidasi dengan cara dilakukan judgment oleh ahli (expert judgement). Pengujian validitas instrument dari 45 item diperoleh 4 item yang tidak valid pada item ke 1, 19, 37, 43, dan 44. Dengan validitas bergrak dari 0,394 sampai dengan 0,764. Reliablilitas skala sebesar $0,946>0,7$ sehingga skala reliable. Teknik analisis data menggunakan statistic deskriptif, dan inferensial dengan uji wilcoxon dan indeks gain.

\section{HASIL DAN PEMBAHASAN}

Keterlaksanaan layanan konseling kelompok berpusat pada klien yang berorientasi religious untuk menurunkan perilaku antisocial siswa di SMA Negeri 1 Kersana persentase skor keterlaksanaan layanan konseling kelompok menggunakan pendekatan berpusat pada klien berorientasi religious untuk menurunkan perilaku antisocial siswa di SMA Negeri 1 Kersana mencapai 86,67\% yang termasuk kategori sangat baik.

Data tentang perilaku antisocial siswa diperoleh melalui angket dengan jumlah item 40 butir, Skor jawaban yang tertinggi adalah 5 dan skor yang terendah adalah 1, sehingga berdasarkan skor tersebut maka variabel perilaku antisocial siswa memiliki rentangan skor antara 40 sampai 200.

\section{Tabel 3.1}

\section{Perilaku Antisosial Sebelum Perlakuan (Pretes)}

\begin{tabular}{|l|l|l|}
\hline \multicolumn{1}{|c|}{ Statistik } & Kel. Eksperimen & Kel. Kontrol \\
\hline Mean & 126,43 & 126,57 \\
\hline Standar Deviasi & 4,12 & 3,46 \\
\hline Max & 132 & 132 \\
\hline Min & 120 & 124 \\
\hline
\end{tabular}


Berdasarkan tabel 3.1 hasil pengumpulan data pada saat sebelum perlakuan mean pada kelompok eksperimen 126,43, deviasi standar 4,12, nilai tertinggi 132, dan nilai terendah 120. Pada kelompok control diperoleh mean 126,57, deviasi standar 3,46, nilai tertinggi 132, dan nilai terendah 124 .

Tabel 3.2.

Distribusi Frekuensi Perilaku Antisosial Kelompok Eksperimen Pretes

\begin{tabular}{|l|l|r|r|}
\hline Interval KK & Kategori & Frekuensi & Persen \\
\hline >Mi + `1SDi & Tinggi & 1 & 14,29 \\
\hline Mi -1SDi - Mi+ 1SDi & Sedang & 6 & 85,71 \\
\hline < Mi - 1SDi & Rendah & 0 & 0,00 \\
\hline Jumlah & 7 & 100,00 \\
\hline
\end{tabular}

Pada tabel 3.2, terlihat bahwa pada kelompok eksperimen sebelum perlakuan (pretes) siswa yang memiliki perilaku antisocial yang tinggi sebanyak 1 responden $(14,29 \%)$, siswa yang berada pada kategori sedang ada 6 siswa $(85,71 \%)$, dan tidak ada responden $(0 \%)$ yang termasuk kategori rendah. Dengan demikian dapat disimpulkan bahwa kelompok eksperimen saat sebelum perlakuan mempunyai perilaku antisocial yang termasuk kategori sedang.

\section{Tabel 3.3}

Distribusi Frekuensi Perilaku Antisosial Kelompok Kontrol Pretes

\begin{tabular}{|l|l|r|r|}
\hline Interval KK & Kategori & Frekuensi & Persen \\
\hline$>\mathrm{Mi}+` 1 \mathrm{SDi}$ & Tinggi & 2 & 28,57 \\
\hline $\mathrm{Mi}-1 \mathrm{SDi}-\mathrm{Mi}+1 \mathrm{SDi}$ & Sedang & 5 & 71,43 \\
\hline < Mi - 1SDi & Rendah & 0 & 0,00 \\
\hline Jumlah & 7 & 100,00 \\
\hline
\end{tabular}

Pada tabel 3.3, terlihat bahwa pada kelompok kontrol sebelum perlakuan (pretes) siswa yang memiliki perilaku antisocial yang tinggi sebanyak 2 responden $(28,57 \%)$, ada 5 responden $(71,43 \%)$ yang berada pada kategori sedang, dan tidak ada responden $(0 \%)$ yang termasuk kategori rendah. Dengan demikian dapat disimpulkan bahwa kelompok control saat sebelum perlakuan mempunyai perilaku antisocial yang termasuk kategori sedang. 


\section{Tabel 3.4}

Distribusi Frekuensi Perilaku Antisosial Kelompok Eksperimen Postes

\begin{tabular}{|l|l|r|r|}
\hline \multicolumn{1}{|c|}{ Interval KK } & Kategori & Frekuensi & Persen \\
\hline$>\mathrm{Mi}+` 1 \mathrm{SDi}$ & Tinggi & 0 & 0,00 \\
\hline $\mathrm{Mi}-1 \mathrm{SDi}-\mathrm{Mi}+1 \mathrm{SDi}$ & Sedang & 1 & 14,29 \\
\hline < Mi - 1SDi & Rendah & 6 & 85,71 \\
\hline Jumlah & & 7 & 100,00 \\
\hline
\end{tabular}

Pada tabel 3.4, terlihat bahwa responden siswa pada kelompok eksperimen setelah perlakuan (postes), tidak ada responden $(0 \%)$ yang memiliki perilaku antisocial yang tinggi, ada 1 responden $(14,289 \%)$ yang termasuk kategori sedang, dan ada 6 responden $(85,71 \%)$ yang termasuk kategori rendah. Dengan demikian dapat disimpulkan bahwa kelompok eksperimen setelah perlakuan (postes) mempunyai perilaku antisocial yang termasuk kategori rendah.

\section{Tabel 3.5}

Distribusi Frekuensi Perilaku Antisosial Kelompok Kontrol Postes

\begin{tabular}{|l|l|r|r|}
\hline \multicolumn{1}{|c|}{ Interval KK } & Kategori & Frekuensi & Persen \\
\hline$>\mathrm{Mi}+{ }^{-1 S D i}$ & Tinggi & 0 & 0,00 \\
\hline $\mathrm{Mi}-1 \mathrm{SDi}-\mathrm{Mi}+1 \mathrm{SDi}$ & Sedang & 1 & 14,29 \\
\hline$<\mathrm{Mi}-1 \mathrm{SDi}$ & Rendah & 6 & 85,71 \\
\hline Jumlah & & 7 & 100,00 \\
\hline
\end{tabular}

Pada tabel 3.5, terlihat bahwa responden siswa pada kelompok control setelah perlakuan (postes), tidak ada responden $(0 \%)$ yang memiliki perilaku antisocial yang tinggi, ada 1 responden $(14,29 \%)$ yang termasuk kategori sedang, dan ada 6 responden $(85,71 \%)$ yang termasuk kategori rendah. Dengan demikian dapat disimpulkan bahwa kelompok control setelah perlakuan (postes) mempunyai perilaku antisocial yang termasuk kategori rendah.

Deskripsi data yang disajikan merupakan data secara umum dari perilaku antisocial siswa yang meliputi: nilai minimal, nilai maksimal, mean, dan standar deviasi. Hasil perhitungan data tersebut dapat dilihat pada tabel berikut:

Tabel 3.6. 
Deskripsi Data Perilaku Antisosial Kedua Kelas

\begin{tabular}{|l|r|r|r|r|}
\hline \multirow{2}{*}{ Statistik } & \multicolumn{2}{|c|}{ Pretes } & \multicolumn{2}{c|}{ Postes } \\
\cline { 2 - 5 } & \multicolumn{1}{|c|}{$\begin{array}{c}\text { Kel. } \\
\text { Eksperimen }\end{array}$} & $\begin{array}{c}\text { Kel. } \\
\text { Kontrol }\end{array}$ & $\begin{array}{c}\text { Kel. } \\
\text { Eksperimen }\end{array}$ & $\begin{array}{c}\text { Kel. } \\
\text { Kontrol }\end{array}$ \\
\hline Mean & 126,43 & 126,57 & 113,86 & 120,86 \\
\hline $\begin{array}{l}\text { Deviasi } \\
\text { Standar }\end{array}$ & 4,12 & 3,46 & 4,81 & 2,41 \\
\hline Max & 132 & 132 & 123 & 124 \\
\hline Min & 120 & 124 & 108 & 118 \\
\hline
\end{tabular}

Berdasarkan tabel 3.6 diatas maka dapat diketahui bahwa nilai hipotetik pretes adalah 126,43 maka nilai maksimumnya diperoleh perhitungan nilai maksimum dikali jumlah item (5 x 40) sehingga hasilnya adalah 200, dan nilai terendah adalah 40. Mean hipotetik dicari dengan skor tertinggi ditambah skor terendah dibagi dua sehingga hasilnya adalah $(200+40=240$ dibagi 2) 120 .

Standar deviasi hipotetik diperoleh dari rentang yaitu nilai maksimum dikurangi nilai minimum (12) lalu dibagi enam sehingga hasilnya adalah 2. Sedangkan rentang data dicari dengan rumus data terbesar dikurangi data terkecil yaitu $132-120=12$.

Berdasarkan tabel diatas maka dapat diketahui bahwa nilai hipotetik setelah perlakuan (postes) maka nilai maksimumnya diperoleh perhitungan nilai maksimum dikali jumlah item sehingga hasilnya adalah 200, dan nilai terendah adalah 40. Mean hipotetik dicari dengan skor tertinggi ditambah skor terendah dibagi dua sehingga hasilnya adalah $(200+40=240$ dibagi $2=120)$ 120. Standar deviasi hipotetik diperoleh dari rentang yaitu nilai maksimum dikurangi nilai minimum lalu dibagi enam sehingga hasilnya adalah $(123-108 / 6=15 / 6)$ 2,5. Sedangkan rentang data dicari dengan rumus data terbesar dikurangi data terkecil yaitu 15 .

Uji normalitas digunakan untuk memastikan apakah sebuah data hasil pengukuran dalam penelitian ini berdistribusi normal atau tidak. Hasil pengujian normalitas dengan teknik Kolmogorov-Smirnov disajikan pada tabel berikut. 
Tabel 3.7

Hasil Uji Normalitas Perilaku Antisosial Kedua Kelompok

\begin{tabular}{|l|l|l|}
\hline \multicolumn{1}{|c|}{ Kelompok } & Nilai Sig. & \multicolumn{1}{c|}{ Kriteria } \\
\hline Pre-E & 0,782 & Data berdistribusi normal \\
\hline Pre-K & 0,017 & $\begin{array}{l}\text { Data tidak berdistribusi } \\
\text { normal }\end{array}$ \\
\hline Pos-E & 0,448 & Data berdistribusi normal \\
\hline Pos-K & 0,196 & Data berdistribusi normal \\
\hline
\end{tabular}

Berdasarkan tabel 3.7, diperoleh nilai signifikan (p) pada variabel perilaku antisocial kelompok eksperimen pretes sebesar 0,782 dan saat postes sebesar 0,448. Dengan demikian dapat disimpulkan bahwa sebaran data pada variabel perilaku antisocial kelompok eksperimen pada saat pretes dan postes berdistribusi normal yang dibuktikan dengan nilai signifikan $(\mathrm{p})>0,05$. Sedangkan pada kelompok kontrol pada saat pretes nilai signifikan (p) 0,017, dan pada saat postes 0,196. Maka dapat disipulkan bahwa nilai pretes kelompok control berditribusi tidak normal, dan nilai postes kelompok control berdistribusi normal. Uji homogenitas digunakan untuk mengetahui apakah antara varian variabel (perilaku antisocial) memiliki varian yang homogen atau tidak. Pengujian terhadap homogenitas varian data dilakukan melalui uji statistik.

Tabel 3.8

Hasil Uji Homogenitas Varian Data

\begin{tabular}{|l|l|l|}
\hline \multicolumn{1}{|c|}{ Statistik Homogenitas } & Nilai Sig. & \multicolumn{1}{c|}{ Kriteria } \\
\hline Pretes & 0,965 & Varian data homogen \\
\hline Postes & 0,242 & Varian data homogen \\
\hline
\end{tabular}

Berdasarkan tabel 3.8, memperlihatkan hasil uji homogenitas varian data perilaku antisocial pada saat pretes adalah homogeny karena diperoleh nilai signifikan (p) 0,965> 0,05. Sedangkan varian data postes juga homogen yang dibuktikan dengan nilai signifikan (p) 0,242>0,05. Dengan demikian dapat disimpulkan bahwa varian data perilaku antisosial pada saat pretes maupun postes adalah homogen.

Untuk mengetahuai perbedaan rerata perilaku antisocial antara sebelum perlakuan (pretes) dan setelah perlakuan (postes) pada kedua kelompok dapat dilihat dengan 
menggunakan uji beda rerata dua sampel ( $t$-test) yang tidak homogeny karena data berdistribusi normal dan varian data tidak homogen. Pengujian statistik yang dibantu dengan SPSS for windows release 20. Adapun hasil uji data penelitian tersebut adalah sebagai berikut:

Tabel 3.9

Hasil Uji Beda Rerata (Wilcoxon-test) Perilaku Antisosial

\begin{tabular}{|c|c|c|}
\hline & Pretes & Postes \\
\hline $\mathrm{Z}$ & $.000^{\mathrm{b}}$ & $-2.032^{\mathrm{b}}$ \\
$\begin{array}{c}\text { Asymp. Sig. (2- } \\
\text { tailed) }\end{array}$ & 1.000 & .042 \\
\hline
\end{tabular}

Dari hasil analisis tersebut didapatkan harga $\mathrm{Z}$ hitung pada saat pretes adalah 0,000 dengan $\mathrm{p}=1,000>0,05$. Jadi hasil dari uji beda rerata dua sampel pretes mengatakan bahwa tidak ada perbedaan yang signifikan perilaku antisosial sebelum perlakuan (pretes) antara kelompok eksperimen dengan kelompok kontrol. Sedangkan setelah perlakuan (postes) diperoleh nilaui $Z$ hitung 2,032 dengan $\mathrm{p} 0,042<0,05$ sehingga dapat disimpulkan bahwa ada perbedaan yang signifikan dari perilaku antisosial setelah perlakuan (postes) antara kelompok eksperimen dengan kelompok kontrol.

Hipotesis merupakan jawaban sementara atas masalah yang dirumuskan. Hipotesis tersebut harus diuji kebenarannya agar dapat memperoleh kesimpulan. Hipotesis dalam penelitian ini adalah " ada perbedaan yang signifikan antara perilaku antisocial siswa kelompok eksperimen dengan kelompok control setelah diberikan perlakuan layanan konseling berpusat pada klien yang berorientasi religious. Sedangkan hipotesis nihil (Ho) pada penelitian ini adalah "tidak ada perbedaan yang signifikan antara perilaku antisocial siswa kelompok eksperimen dengan kelompok control setelah diberikan perlakuan layanan konseling berpusat pada klien yang berorientasi religious.

Setelah dilakukan uji normalitas, homogenitas, selanjutnya dilakukan pengajuan hipotesis dengan menggunakan analisis beda rerata dua sampel (wilcoxon-test) untuk mencari perbedaan dua rata-rata sampel perilaku antisocial siswa kelas X di SMA Negeri 1 Kersana. Pengajuan hipotesis digunakan teknik analisis Wilcoxon-test yang dihitung menggunakan program SPSS for Windows versi 20. 
Dari hasil analisis diketahui bahwa tidak ada perbedaan yang signifikan dari perilaku antisocial antara responden siswa kelompok eksperimen dengan kelompok control sebelum perlakuan yang dibuktikan dengan nilai signifikan (p) 1,000 > 0,05. Setelah kedua kelompok diberikan perlakuan layanan konseling berpusat pada klien yang berorientasi religious kemudian dilakukan pengujian statistik diketahui bahwa ada perbedaan yang signifikan dari perilaku antisocial antara responden siswa kelompok eksperimen dengan kelompok control setelah perlakuan yang dibuktikan dengan nilai signifikan (p) 0,042<0,05. Dengan demikian hipotesis alternatif ( $\mathrm{Ha}$ ) yang berbunyi ada perbedaan yang signifikan dari perilaku antisocial responden siswa antara kelompok eksperimen dengan kelompok control setelah perlakuan di kelas X di SMA Negeri 1 Kersana diterima/terbukti.

Untuk mengetahui tingkat efektifitas layanan konseling kelompok menggunakan pendekatan berpusat pada klien yang berorientasi religius untuk menurunkan perilaku antisocial siswa dilakukan dengan melakukan pengujian indeks Gain ternormalisasi sebagaimana tabel berikut.

\section{Tabel 3.10}

Hasil Uji Indeks Gain

\begin{tabular}{|l|l|l|c|l|}
\hline \multicolumn{1}{|c|}{ Kelas } & Rerata Pretes & Rerata Postes & $\mathrm{g}>$ & Kriteria \\
\hline Eksperimen & 126,43 & 113,86 & 0,475 & Sedang \\
\hline Kontrol & 126,57 & 120,86 & 0,21 & Rendah \\
\hline
\end{tabular}

Tabel 3.10 memperlihatkan hasil pengujian indeks gain ternormalisasi dari perilaku antisocial siswa sebelum dan setelah perlakuan. Berdasarkan tabel di 4.10 atas terlihat bahwa indeks gain kelompok eksperimen adalah 0,475 yang termasuk kategori sedang, dan indeks gain kelmpok kontrol adalah 0,21 yang termasuk kategori rendah. Dengan demikian terjadi penurunan perilaku antisocial dari kedua kelompok, dan penurunan perilaku antisocial pada kelompok eksperimen lebih tinggi daripada kelompok kontrol. Jadi dapat disimpulkan bahwa layanan konseling kelompok menggunakan pendekatan berpusat pada klien yang berorientasi religious efektif untuk menurunkan perilaku antisocial siswa. 
Berdasarkan hasil analisis data, perilaku antisocial siswa yang terdiri dari 9 dimensi disajikan pada table berikut ini.

Tabel 3.11

Perilaku Antisosial Siswa Kelompok Eksperimen Per indicator

\begin{tabular}{|l|r|r|r|}
\hline Indikator & \multicolumn{1}{|l|}{ Pretes (\%) } & Postes (\%) & \multicolumn{1}{|c|}{ Beda (\%) } \\
\hline Self Control & 55,24 & 55,24 & 0,00 \\
\hline Self Esteem & 63,81 & 61,43 & 2,38 \\
\hline Ketidaktaatan & 50,71 & 50,36 & 0,35 \\
\hline Avoidance & 65,71 & 64,76 & 0,95 \\
\hline Resentment & 72,86 & 67,14 & 5,72 \\
\hline Iritabilitas \& Agresi & 72,86 & 64,29 & 8,57 \\
\hline Penyimpangan & 62,86 & 61,43 & 1,43 \\
\hline Irresponsibility & 64,76 & 61,90 & 2,86 \\
\hline Kurang penyesalan & 68,57 & 66,67 & 1,90 \\
\hline
\end{tabular}

Tabel 3.11 memperlihatkan bahwa perilaku antisocial siswa per indicator pada dimensi self control pada saat pretes 55,24\% setelah perlakuan menjadi 55,24\% sehingga terjadi penurunan 0\%. Pada dimensi self esteem pada saat pretes $63,81 \%$ kemudian setelah perlakuan (postes) menjadi 61,43\% dengan penurunan 2,38\%. Pada dimensi ketidaktaatan pada saat pretes $50,71 \%$ setelah postes menjadi $50,36 \%$ dengan penurunan $0,35 \%$. Pada dimensi penghindaran (avoidance) pada saat pretes $65,71 \%$ dan pada saat postes 64,76 dengan penurunan 0,95. Pada dimensi rasa dendam (resentment) saat pretes 72,86 dan pada saat postes 67,14 dengan penurunan 5,72. Pada dimensi iritabilita dan agresi saat pretes 72,86 dan pda saat postes 64,29 dengan penurunan $8,57 \%$. Pada dimensi penyimpangan (deviance) saat pretes 62,86 dan saat postes 61,43 dengan penurunan 1,43\%. Pada dimensi irresponsibility saat pretes 64,76 dan saat postes 61,90 dengan penurunan 2,86. Pada dimensi kurangnya penyesalan dari $68,57 \%$ turun menjadi $66,67 \%$ dengan selisih 1,90\%. Dengan demikian dapat disimpulkan bahwa perilaku antisocial siswa mengalami penurunan setelah diberikan perlakuan layanan konseling kelompok menggunakan pendekatan berpusat pada klien yang berorientasi religious, dengan selisih penurunan tertinggi pada dimensi iritabilitas dan agresi.

Telah diketahui bahwa masa remaja dianggap sebagai usia bermasalah, menurut Irwanto (2017) setiap periode mempunyai masalahnya sendiri-sendiri, namun masalah 
masa remaja sering menjadi masalah yang sulit diatasi, baik oleh anak laki-laki maupun anak perempuan. Menurut Willis (2012:1) masa remaja adalah suatu tahap kehidupan yang bersifat peralihan dan tidak mantap, serta masa yang rawan oleh pengaruh-pengaruh negatif, seperti narkoba, kriminal, dan kejahatan seks. Berdasarkan uraian tersebut dapat dipahami bahwa masa remaja merupakan masa yang tidak mantap, remaja mengalami peralihan dan pencarian jati diri. pada masa remaja dianggap sebagai usia bermasalah yang sering ditandai oleh sifat-sifat negatif pada diri remaja, sehingga masa ini seringkali disebut fase negatif karena rawan oleh pengaruh negatif seperti narkoba, kriminal, kejahatan atau kekerasan, dan perilaku antisosial yang lain.

Berdasarkan hasil penelitian ini diperoleh informasi bahwa perilaku antisocial siswa masing-masing dimensi mengalami penurunan setelah diberikan perlakuan layanan konseling kelompok menggunakan pendekatan berpusat pada klien yang berorientasi religious. Penurunan maksimal pada dimensi Iritabilitas dan agresi (8,57\%), dan penurunan minimal pada dimensi self control. Hal ini sesuai dengan teori bahwa remaja sering dideskripsikan agresif karena mengambil apa saja yang mereka inginkan, tanpa peduli perasaan orang lain. Remaja sering tidak melihat perbedaan antara kebenaran dan kebohongan ucapannya demi mencapai tujuannya. Mereka tidak menunjukkan penyesalan atau peduli pada efek-efek tindakannya yang kadang-kadang sangat merusak. Sebaliknya, karena nilai-nilai konservasi menekankan pentingnya kepatuhan dan penghormatan terhadap aturan, diharapkan pentingnya nilai-nilai sosial ini untuk mencegah adopsi perilaku antisosial (Danioni \& D. Barni, 2017). Individu dengan perilaku antisosial biasanya secara terus menerus melakukan tingkah laku antisosial, meskipun ini tidak sama dengan kriminalitas. Gangguan perilaku ini lebih menekankan pada ketidakmampuan individu untuk mengikuti norma-norma sosial yang ada selama perkembangan remaja dan dewasa (Delisi, 2018).

Hasil penelitian ini mendukung hasil penelitian sebelumnya oleh Setyawati (2013) yang menyimpulkan bahwa tingkat ketaatan siswa sesudah mendapatkan perlakuan layanan konseling kelompok dengan teknik client centered therapy nilai mean skor pretes sikap terhadap tata tertib sekolah sebesar 57,4 nilai rerata ini mengalami peningkatan dengan sebelum mendapatkan perlakuan konseling kelompok dengan teknik client centered therapy. 
Hasil penelitian ini senada dengan penelitian Irwanto (2017) tentang peranan konseling islami untuk menurunkan perilaku agresif siswa yang menyimpulkan bahwa penerapan konseling islami terhadap masalah siswa berperilaku agresif menunjukkan adanya perubahan perilaku siswa menjadi tidak agresif

Secara umum proses guru BK dalam melaksanakan proses konseling berorientasi religious sama dengan guru BK pada umumnya yakni menentukan masalah, pengumpulan data, analisis data, diagnosis,prognosis, terapi, evaluasi atau Follow-up. Namun, ketika pada waktu awal proses konseling membaca surat-surat pendek seperti surat Al-Fatihah dan Al-Ikhlas tujuannya agar hati menjadi tentram, ketika memasukkan unsur-unsur atau nilai-nilai Islam dalam melaksanakan proses konseling guru BK menggunakan nilai-nilai Islam tersebut sesuai dengan masalah yang dihadapi oleh siswa.

Dengan demikian dapat dijelaskan bahwa adanya pelaksanaan layanan konseling kelompok menggunakan pendekatan berpusat pada klien yang berorientasi religious yang sangat baik dapat berpengaruh terhadap perilaku antisocial siswa di SMANegeri1 Kersana.Hal ini dibuktikan dengan adanya perbedaan perilaku antisocial antara sebelum perlakuan dengan setelah perlakuan dimana perilaku antisocial setelah perlakuan layanan konseling kelompok menggunakan pendekatan berpusat pada klien yang berorientasi religious, perilaku antisocial responden siswa menurun.

Hasil penelitian ini juga senada dengan penelitian Ratnawati (2017) tentang Penerapan Person Centered Therapy di Sekolah (Empathy, Congruence, unconditional Positive Regard) dalam Manajemen Kelas yang menyimpulkan bahwa layanan person centered therapy mungkin tidak menawarkan solusi yang siap jadi atau mengarahkan klien untuk mengikuti strategi mengatasi masalah tertentu. Apa yang dilakukan konselor adalah menggunakan kesempatan dalam hubungan kepercayaan melalui penghargaan terhadap klien sehingga masalah yang dihadapi dapat diselesaikan. Secara keseluruhan, klien diasumsikan dapat memiliki kemampuan untuk membuat solusi atas permasalahannya, dan terapis hanya bertindak sebagai teman dalam proses penyembuhan

\section{KESIMPULAN}

Berdasarkan hasil penelitian dan pembahasan maka dapat ditarik simpulan sebagai berikut :

1. Keterlaksanaan konseling kelompok melalui pendekatan berpusat pada klien yang 
berorientasi religius mencapai $86,67 \%$ yang termasuk kategori sangat baik.

2. Layanan konseling kelompok melalui pendekatan berpusat pada klien yang berorientasi religius efektif untuk menurunkan perilaku antisocial siswa yang dibuktikan dengan nilai $\mathrm{Z}_{\text {hitung }}$ 2,032 $>\mathrm{t}_{\text {table }}$ 1,96 dengan nilai probabilitas ( $p$ value) $\mathbf{0 , 0 4 2}<\mathbf{0 , 0 5}$, dengan nilai indeks gain 0,475 yang termasuk kategori sedang.

\section{DAFTAR PUSTAKA}

Arizona., Mungin Eddy W., M. Japar (2016). Teknik Relaksasi Berbasis Musik Instrumental Meningkatkan Self Efficacy Siswa SMP Melalui Pengembangan Model Konseling Kelompok. Jurnal Bimbingan Konseling Vol.56 No.2 tahun 2016. http://journal. unnes.ac.id/sju/index.php/jubk.

Ashari, W., DYP Sugiharto, Supriyo. (2016) Pengembangan Model Konseling Kelompok dengan Teknik Pengelolaan Diri untuk Meningkatkan Efikasi Diri Siswa di SMK YPT 1 Purbalingga. pp. 126-133. Jurnal Bimbingan Konseling Vol.5 No.2 tahun 2016. http://journal. unnes.ac.id/sju/ index.php/jubk.

Biondi, D.D., Mulawarman., Mungin Eddy Wibowo (2018). Creative counseling: Integration of counseling in cognitive behavior therapy groups with passive music therapy to improve self-efficacy of students of millennial. Jurnal Konselor Vol.7 no.2 Tahun 2018. http://ejournal.unp.ac.id/ index.php/ konselor/ article/ view/ 10294.

Danioni, F., \& Daniela Barni (2017). The relations between adolescents' personal values and prosocial and antisocial behaviours in team sports. International Journal of Sport and Exercise Psychology, August 2017. Pp. 1-19. https://www.researchgate.net/publication/314188103_Transmitting_Sport_Val ues_The_Importance_of_Parental_Involvement_in_Children's_Sport_Activity

Desousa, A. (2014). Berpusat pada Klien Therapy. Indian Journal of Applied Research. Volume 4 Issue 2 Februari 2014. pp 10-13. https://www.worldwidejournals. com/indian-journal-of-applied-research-(IJAR)/articles. php? val=MzIyMA== \& $\underline{\mathrm{b} 1=37 \& \mathrm{k}=10}$

Dwistia, H., Edy Purwanto., Sunawan (2016). Keefektifan Konseling Kelompok dengan Strategi Self Management dalam Meningkatkan Classroom Egagement Siswa. Jurnal Bimbingan Konseling Vol. 5 No.2 tahun 2016.http://journal. unnes.ac.id/sju/index.php/jubk.

Efastri, S.M., Rustono, Mungin Eddy Wibowo. (2015). Keefektifan Konseling Kelompok dengan Pendekatan Behavioral untuk Mengurangi Perilaku Bullying, Perilaku Agresif. Jurnal Bimbingan Konseling Volume 4 No.2 Tahun 2015. Pp. 17.http://journal. unnes.ac.id/sju/index.php/jubk. 
Hidayanti, S.F., M. Ja'far. (2016) Keefektifan Self Instruction dan Cognitive Restructuring untuk Mengurangi Perilaku Membolos Siswa. Jurnal Bimbingan Konseling Vol. 6 No.2 tahun 2017. http://journal. unnes.ac.id /sju/index.php/jubk.

Irwanto, Z. 2017. Perilaku agresif dan penangananya melalui konseling islami. Jurnal Psikologi Pendidikan \& KonselingVolume 3 Nomor 1 Juni 2017. Hal 27-34. Homepage: http://ojs.unm.ac.id/index.php/JPPK

Khomsah, N.R., Heru Mugiarso., Kusnarto K. (2018). Layanan Konseling Kelompok untuk Meningkatkan Resiliensi Siswa. Jurnal Bimbingan Konseling Vol.7 No.2 tahun 2018. http://journal. unnes.ac.id/sju/index.php/jubk.

Nugraha, A.K. (2017). Efektifitas Penggunaan Konseling Kelompok Dengan Teknik Berpusat pada Klien Untuk Mengatasi Kenakalan Remaja Pada Siswa SMP Negeri 5 Karanganyar. https://eprints.uns.ac.id

Park, Juhyung. (2018).The influences of client-centered therapy on the level of performance, the level of satisfaction of activity of daily living, and the quality of life of the chronic stroke patients. The Journal of Physical Therapy Science Vol.30 No.2 2018. https://www.ncbi.nlm.nih.gov > pubmed

Prayitno. (2008). Dasar-Dasar Bimbingan dan Konseling. Jakarta: Rineka Cipta.

Puspita, R., DYP Sugiharto, Sugiyo. (2019). Group Counseling with Cognitive Therapy Group and Extinction Techniques to Reduce Academic Procrastination. . Jurnal Bimbingan Konseling Vol. 10 No.1 tahun 2019. http://journal. unnes.ac.id/sju/index.php/jubk.

Ratnawati, V. (2017). Penerapan Person Centered Therapy di Sekolah (Empathy, Congruence, Unconditional Positive Regard) dalam Manajemen Kelas. Journal of Education Technology. Vol. 1 No. 4. pp. 252 - 259

Setyawati, Suerlin. (2013). Konseling Kelompok Dengan Teknik Berpusat pada Klien Therapy Dalam Meningkatkan Ketaatan Terhadap Tata Tertib Sekolah. Jurnal Universitas Muhammmadiyah Yogyakarta, 2013.

Wibawa, A.EY., Anwar Sutoyo, Sugiyo. (2015). Pengembangan Model Konseling Kelompok Behavior Dengan Teknik Modeling untuk Meningkatkan Kedisiplinan Siswa SMA Kabupaten Lamongan. Jurnal Bimbingan Konseling Volume 4 No.2 Tahun 2015. pp. 85-91. https://journal.unnes.ac.id > sju > index.php > jubk

Wibowo, M.E (2019). Konseling Kelompok Perkembangan. Semarang: UPT Unnes Press. 